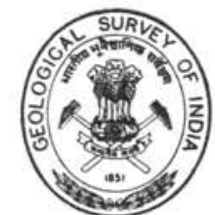

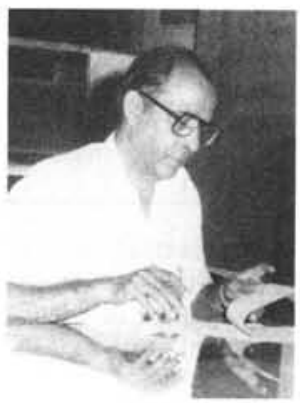

\section{Sailen Mukerjee IUGS Vice-President}

To a lad growing up in Calcutta on the flat alluvial plain of the River Ganges, rocks and hills are things of fascination, for to see them one has to travel at least $100 \mathrm{~km}$ from the city. Thus it was that the young Sailen Kumar Mukerjee acquired an interest in geology. As it happened, Calcutta's Presidency College was then one of the few Indian institutions teaching geology, and he was fortunate to secure a place there. Under the guidance of Prof. N.N. Chatterjee, an expert in economic geology, especially coal, he earned his B.Sc. honours degree in 1947 and, two years later, his M.Sc. in Economic Geology.

Life for a professional geologist was exciting in those days, for immediately after India gained its independance there was a great push to set up heavy industries, and crash programs were launched to establish the necessary natural resource base. Upon graduation, Mr. Mukerjee joined a private company searching for bedded iron ores and lateritoid maganese deposits, and in 1955 he switched to the government-owned Hindustan Steel Company where he was involved in locating and assessing ore reserves for a million tonne steel plant.

One of his tasks at Hindustan Steel was to study the nature of the ore fines for agglomeration, and he was also responsible for ensuring the availability of refractory grade dolomite suitable for the calcination process. During this period, $\mathrm{Mr}$. Mukerjee became interested in the problems of iron ore formation, especially as regards the origin of blue dust, and the trace element distribution in the different iron belts on India. Indeed, he still has a "pious desire of looking into this problem when I can find time."

By 1965, a huge increase in the raw materials for India's steel industry had been firmly established, and the pace of exploration activity slackened. Following a two year stint with the Indian Bureau of Mines, Mr. Mukerjee joined the Geological Survey of India (GSI) in 1967. Apart from a brief period in the early 1970s with the Mineral Exploration Corporation in Nagpur, he has been with the Survey ever since, rising through its ranks to Deputy Director General in charge of the Shillong regional office and then to Director General in 1982.

The GSI is one of the oldest and largest geological surveys in the world. Founded in 1851 , it now employs some 2,500 scientists and 11,000 support staff, and about 100 M.Sc. and Ph.D. graduates are taken in every year. Working from a national headquarters in Calcutta and nearly 30 regional units scattered throughout the country, about $70 \%$ of the GSI seientists are in the geology "stream," with the balance in geochemistry and geophysics.

The two major functions of the GSI are the generation of the data through geological, geophysical and geochemical mapping, geo-environmental studies and laboratory research, and through the application of these data in the exploration for resources and in dealing with natural hazards. Though regional mapping is still an important activity - some $70 \%$ of the country has now been mapped at seales of $1: 50,000$ or $1: 63,360$ - the annual program of the GSI is substantially demand-oriented; it is drawn up through extensive consultations with user agencies involved in the exploitation of non-renewable resources. Mr. Mukerjee, thus, calls himself "an earth science manager guiding the scientific activities of and helping in resource mobilization" for the GSI.

Although the GSI has no specific international role, it is naturally involved in international governmental organizations such as the United Nations, and in worldwide cooperative programs like CGMW and IGCP. Several of the IGCP projects have been led by GSI scientists, and the Survey has produced, on contract, maps for the CGMW. There are also several bilateral research programs involving GSI scientists and foreign geologists, such as on the Son-Narmada lineament (with the U.S.A.). Sailen Mukerjee commends the IUGS for its role in helping to overcome the isolation of geoscientists in south Asia and elsewhere. As he says, IUGS can bring the "wide world of the geosciences" closer together, increasing the interaction of ideas and people for the benefit of science, the region and the worldwide scientific community.

For Sailen Mukerjee, one of his country's most prominent geoscientists, geology has been both rewarding and absorbing. He regards himself as fortunate for having been able to fit into the long tradition of geology in India and says that the "heritage imbibed has been a great support in my professional career."

\section{IN MEMORIAM}

- Erich Dimroth, 51, professor since 1975 at the University of Quebec in Chicoutimi. Former leader of IGCP Project 160 , he was widely known for his research on Precambrian sediments and volcanics.

- John W. Pallister, 73, long-time geologist with the Colonial Geological Survey, later the Overseas Division of the Institute of Geological Sciences (U.K.). Senior geologist with governments of Uganda, British Somaliland, and Tanzania, he also worked as a geologist in Zambia, Sarawak, Papua, India and Australia.

- Paul Ramdohr, 95, in Heidelberg, F.R.G. A giant in the field of mineralogy and ore genesis, author of many influential papers and books, he held posts at universities in Clausthal, Aachen, Berlin and from 1950 on at Heidelberg. Ramdohr provided critical evidence for the now prevailing synsedimentary interpretations of major ore deposits at Rammelsberg, Broken Hill and the Witwatersrand.

- Charles F. Richter, 85, in Pasadena, California. Pioneer seismologist who developed the numerical scale for earthquake magnitudes that now bears his name.

- Francis P. Shepard, 87, of La Jolla, California. Founder of the modern field of marine geology, Professor Emeritus at Scripps Institution of Oceanography and author of many authoritative books on, for example, submarine canyons, geological oceanography, coastlines and the ocean floor. 


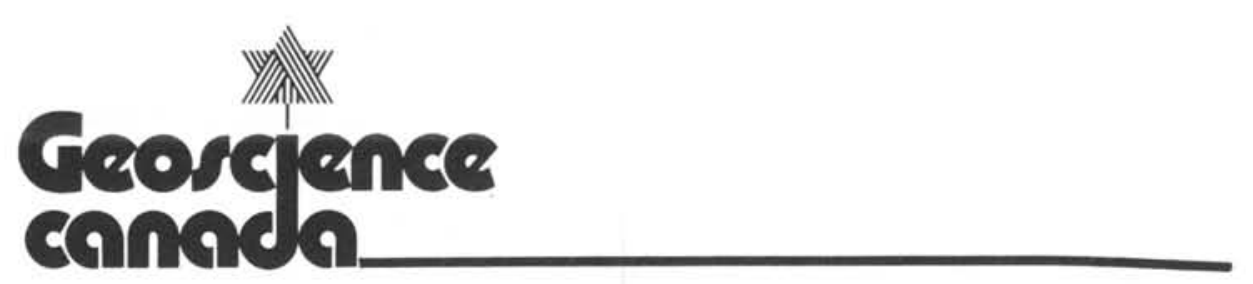

\section{QUARTERLY JOURNAL OF THE GEOLOGICAL ASSOCIATION OF CANADA}

G

eoscience Canada is a non-specialist journal covering all aspects of the geological sciences, with state-of-the-art reviews and summaries of interest to professional geoscientists working in industry, university, government and private practice.

Each issue contains referreed articles, conference reports, book reviews and a variety of regular features. Many of the articles form part of specially-commissioned series on subjects of current importance. An earlier series on Facies Models has been reprinted as a best-selling text now in its second edition, and another collection on Methods of Dating Pleistocene Deposits has just been released.

\section{RECENT ARTICLES ON:}

- Success in mineral exploration: a matter of confidence

- Paleomagnetism for geologists

- Thermal background to metamorphism

- Mafic dyke swarms and geodynamic processes

- Slope stability and land use in mountain valleys
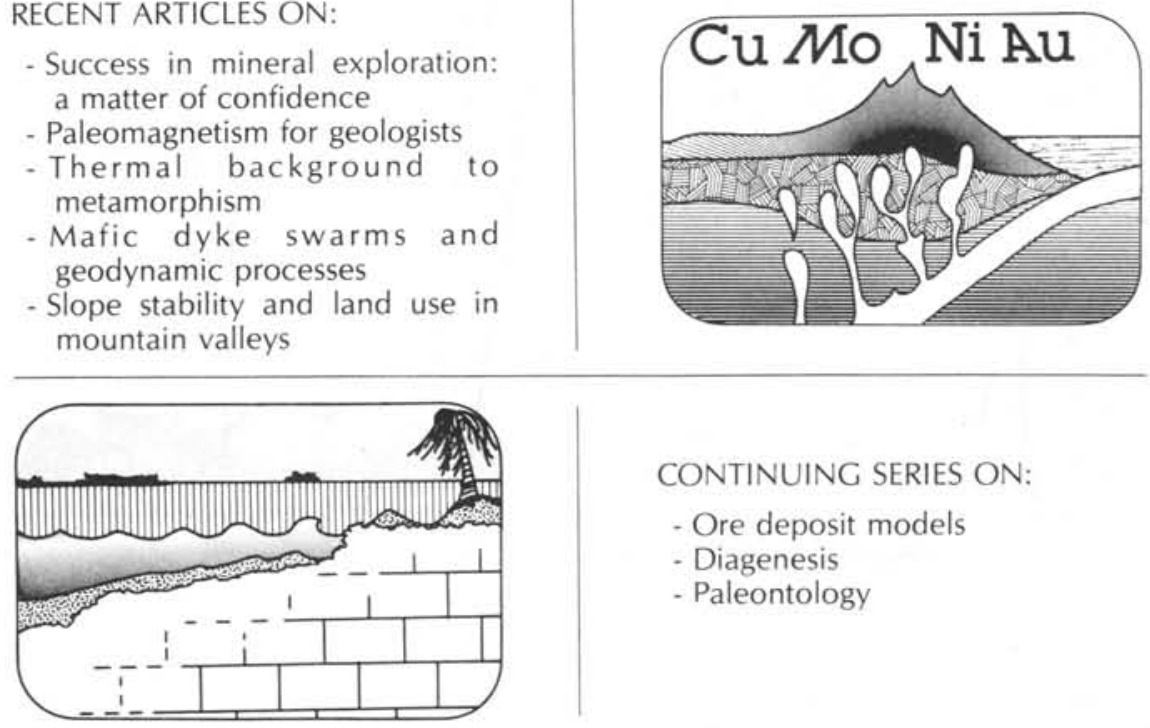

\section{CONTINUING SERIES ON:}

- Ore deposit models

- Diagenesis

- Paleontology

\section{FEATURES:}

- Pyroclasts (topical comments on issues of national importance)

- Machinations (innovations in analytical equipment and procedures)

- Active Earth (short-term geological processes)

- History of Canadian Geology

\section{CONFERENCE REPORTS}

DISCUSSIONS

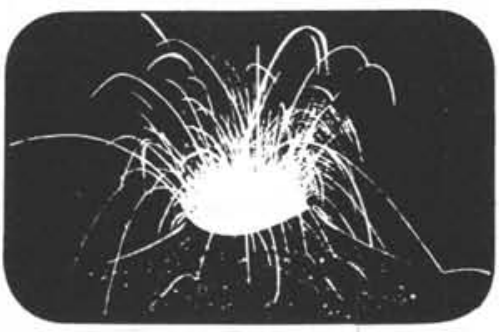

BOOK REVIEWS

POSITIONS AVAILABLE

PLEASE ENTER MY SUBSCRIPTION TO GEOSCIENCE CANADA for 198 (Available on calendar year basis only. Single issues $\$ 7.50$ each)

VISA or MASTERCARD (a) $\$ 25.00$ (Canadian) Expiry Date: Signature:

Payment by cheque or money order may also be made in equivalent U.S. funds. Payment must accompany order. Make cheques payable to Geological Association of Canada. Mail orders to GAC Publications, Business and Economic Service Ltd., 111 Peter Street, Suite 509, Toronto, Ontario, M5V-2H1. Canada.

Name: 